Click www.researchjournal.co.in/online/subdetail.html to purchase.

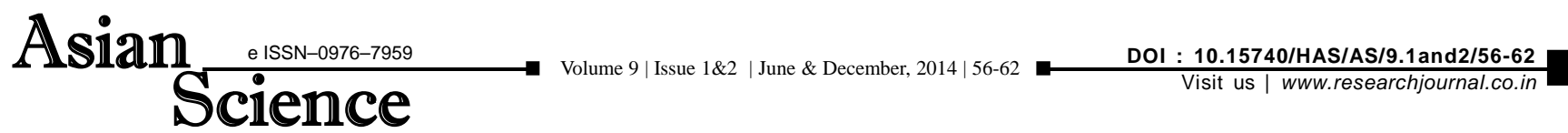

RESEARCH PAPER

\title{
In vitro anticancer and hepatoprotective activity studies of Garcinia xanthochymus
}

\author{
S.J. PRASHANTH, D. SURESH*, V.H. POTTY AND P. SADANANDA MAIYA \\ Dr. P. Sadananda Maiya Centre for Food Science and Research, Jayanagara, BENGALURU (KARNATAKA) INDIA
}

\begin{abstract}
Natural products are very well known to exhibit anticancer activities. The present study aimed at assessing the potency of various extracts of Garcinia xanthochymus against cancer using in vitro cell lines. MCF 7, HepG2, HeLa, PC3, A549 and Vero cell lines were employed for the assessment. The ability of extracts to exert toxic insult on cancer cells has been the basis of anticancer activity. GxF was fond to be very potentially toxic $(80 \mathrm{mg} / \mathrm{ml})$ to HEP G2 cell lines among all the tested extracts. Also, it was found to be the most toxic compared to GxA and GxF whose average $\mathrm{CTC}_{50}$ was found to be 180 and $118 \mathrm{mg} / \mathrm{ml}$, respectively. Among all the tested extracts, GxF was found to be potentially toxic to the MCF 7 cell lines whose $\mathrm{CTC}_{50}$ was found to be $73 \mathrm{mg} / \mathrm{ml}$. GxA possesses the CTC 50 of $810 \mathrm{mg} /$ $\mathrm{ml}$. GxR was found to be toxic with average $\mathrm{CTC}_{50}$ of $303 \mathrm{mg} / \mathrm{ml}$. This was followed by GxF and GxA with average CTC $\mathrm{C}_{50}$ values of 303 and $456 \mathrm{mg} / \mathrm{ml}$. In vitro hepatoprotective activity of the plant extracts was studied by employing primary rat hepatocytes. The drug silymarin was found to exhibit 85.28 per cent protection against paracetamol induced toxicity in primary rat hepatocytes at the tested concentration of $250 \mathrm{mg} / \mathrm{ml}$. It was found that GxF and GxR were found to have comparatively similar protective power like silymarin. These extract exhibited 83.63 per cent and 79.58 per cent protection against paracetamol induced toxicity in primary rat hepatocytes at the concentration of $200 \mathrm{mg} / \mathrm{ml}$, respectively. GxA did not exhibit considerable activity with 55.61 per cent protection.
\end{abstract}

Key Words : Garcinia xanthochymus, In vitro, Anticancer, Hepatoprotective, Cell lines

View point paper : Prashanth, S.J., Suresh, D., Potty, V.H. and Maiya, P. Sadananda (2014). In vitro anticancer and hepatoprotective activity studies of Garcinia xanthochymus. Asian Sci., 9 (1\&2): 56-62.

\footnotetext{
* Author for correspondence

D. Suresh, Department of Studies and Research in Chemistry, Tumkur University, TUMKUR (KARNATAKA) INDIA (Email: pbdsuresh@ gmail.com)
} 